\title{
潤滑油における基油の役割と高引火点潤滑油について Roll of Base Oil in Lubricants and Trends of High Flash Point Type Lubricants
}

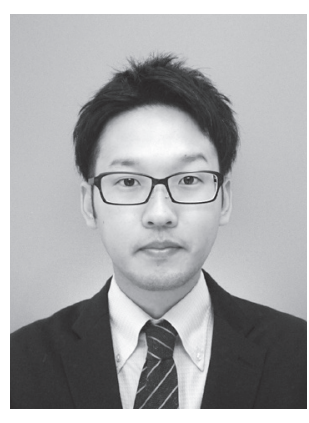

\author{
岡野 知晃 \\ 出光興産株式会社 潤滑油二部 \\ 営業研究所 加工油グループ \\ 干 299-0107 \\ 千葉県市原市姉崎海岸 24-4 \\ Tomoaki OKANO \\ Metal Working Oil Group, Lubricant Research \\ Laboratory, Idemitsu Kosan Co., Ltd. \\ 24-4, Anesakikaigan, Ichihara-shi, \\ Chiba 299-0107, Japan
}

論文要旨：潤滑油は「機械の血液」と呼ばれており，機械を動かす上で重要な構成要素である。潤滑油は 主にベースオイル（基油）と添加剤から構成されており，潤滑油の基本性能はベースオイルによって大きく 左右されるため, 非常に重要な役割を担っている。本項では潤滑油におけるべースオイルの役割について解 説すると共に, 潤滑油を取り巻く法規制への対応の一例として, 潤滑油の高引火点化による消防法への対応 およびその効果について紹介する。

\begin{abstract}
Lubricant is a very important component of machine which contributes to their stable operations. Its basic performance mostly depends on the base oil that composes 80 to $90 \%$ of the Lubricant itself. In addition to above mentioned, there are many kinds of base oil and we have to choose the most appropriate one for operating environment of Lubricant. On the other hand, there is a growing need for high-performance Lubricant corresponding to the enhancement of laws and regulations all over the world. In this review, we summarize the property and application of base oil, in particular, the mineral, synthetic and vegetable types. Furthermore, we introduce an example of the countermeasures and its results for the Fire Defense Law compliance, in consideration of the change of the Lubricant to high flash point type.
\end{abstract}

Key words: lubricant, base oil, tribology, legal compliance, high flash point

\section{1 はじめに}

有史以来, ものとものが動く界面には摩擦・摩耗とい う現象が生じることが知られており，人類は如何にこれ ら摩擦・摩耗を減らせるか, つまり「潤滑」させるかと いった取り組みが行われてきた。潤滑の手法としては液 体（潤滑油）を添加することが古来より知られており， 紀元前に描かれたとされるエジプト時代の壁画には，石 像を動かすためにオリーブ油（と考えられている液体） を用いている様子が既に描写されていることからも, 潤 滑油のアプリケーションにおける歴史の深さを垣間見る ことが出来る ${ }^{1)}$ 。

潤滑油の主な適用が石像の運搬から機械の稼動に移つ

連絡者: 岡野 知晃

E-mail : tomoaki.okano.1000@idemitsu.com
た現代においても，潤滑油は「機械の血液」と呼ばれる ほど機械が正常に稼㗢するためには必要不可欠な要素で あることが広く知られている。18 世紀半ばにイギリス で起こった産業革命から約 250 年が経過するが, その間 にも機械文明は著しい発展を遂げ, 潤滑油技術もその発 展に伴い著しく多様化・高性能化してきた。産業革命期 （1730 年代～1820 年代頃）までは, 動植物に由来する油 脂類が潤滑油として用いられてきたが，1850 年頃の英 国にて鉱物油系潤滑油が開発され，1857 年に米国にて 原油の機械掘りに成功してから, 潤滑油の原料は現在で も主流である石油へと転換していくこととなった ${ }^{2)}$ 。

これら歴史を経た今日の潤滑油の主構成要素は, ベー スオイル（基油）と添加剤とから成り立っており，中で もベースオイルは凡そ 8 割〜 9 割を占めている。もちろ ん潤滑油技術を論ずるにあたっては, 残りの 1 割〜2 割 
の添加剂配合（処方）技術が重要となってくるわけであ るが，潤滑油への要求がどれだけ厳しくなっても潤滑油 の基本性能はベースオイルによって大きく左右されるた め, ベースオイルの品質向上は潤滑油製品の性能向上に かかせない。さらに近年は, 地球温暖化の深刻化に伴い, 機械の設計思想は高性能化から高効率化へと移行してお り, これらの動きに合わせて潤滑油も, 環境対応, 低毒 性, 生分解性といった新たな性能や物性への要求が追加 されつつあり，ベースオイルが担う役割というものも従 来以上に大きくなりつつある。

本稿では，時代の変化に伴い目まぐるしく変化する潤 滑油を取り巻く法規制・環境に対して, 潤滑油開発では 如何にブレイクスルーを実現してきたか，ベースオイル という観点に着目し，概説する。

\section{2 ベースオイルの種類とそれぞれの特徵}

潤滑油に使用される主なベースオイルを Table 1 に示 す。ベースオイルは鉱物油系，合成油系，植物油系に大 別することが可能であり，それぞれの特徵に合わせて 様々な潤滑油が開発されている。

鉱物油系ベースオイルはその名のとおり原油から蒸 留・精製されたものであり，1920 年代に溶剂精製法や 脱蝉工程と言った精製工程が確立されて以降，鉱物油系 ベースオイルが広く普及することとなった ${ }^{3)}$ 。加えて第 二次世界大戦以降の産業の大幅な進歩, 機械の高性能化 に伴い，潤滑油に要求される性能も年々高まり，更なる 高精製基油が求められる分野が増えてきた。これら要求 に応えるべく，1970 年代には水素化処理法が開発され， 1980 年代にはベースオイルに含まれるワックス分の異 性化による高粘度指数・低流動点ベースオイルが，また 2000 年代にはフィッシャー・トロプシュ法を利用した 天然ガスの液化プロセスによる，GTL（Gas to Liquid） 系ベースオイルなどが開発・実用化され，特に潤滑油の
熱・酸化安定性, 省然費化といった性能向上に大きく寄 与してきた ${ }^{4)}$ 。

合成油系ベースオイルは 1930 年代にドイツや日本な どの石油資源を持たない国が，鉱油に代わって $\alpha$-オレ フィンオリゴマーからジエステル，ポリオールエステル といった合成基油を開発したことに端を発した形で多く の研究・生産が開始された ${ }^{5)}$ 。その後, ポリ $\alpha$ オレフィ ン（PAO）やポリアルキレングリコールといった合成 系ベースオイルが多く開発・実用化されてきたが，その 製造方法が鉱油より複雑であり, 生産量も少ないことか ら，性能は優れているにも関わらず経済性の観点からま だまだ特殊用途での使用が主である。しかし，近年の法 規制の厳格化や環境意識の高まりより，合成油系ベース

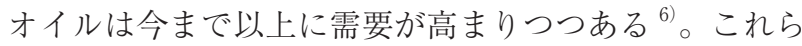
ニーズにおける合成油系ベースオイルの寄与について は，詳細を後述する。

植物油系ベースオイルは, その名のとおり植物由来の エステル系基油であり，グリセロール 1 分子に脂肪酸 3 分子がエステル結合したトリアシルグリセロールを主と して構成されている ${ }^{7,8)}$ 。特に生分解性に優れており, 環境中に漏洩した場合でも, 比較的少量であれば自然界 のバクテリアなどによって，炭酸ガスと水に分解される ことから, 環境への漏洩が懸念される森林や水源地の建 設機械，船用エンジンなどに幅広く使用されている。

このように潤滑油のベースオイルだけでも様々な種類 があり，時代の変遷および社会のニーズに合わせて，そ れぞれの特徴を考慮した潤滑油技術開発が為されてきた ことがわかる。近年の環境・法規制における潤滑油のベー スオイルを用いた対応は, 省エネ・エコマークへの取組 み等これまでも多く実例があるが，中でも潤滑油の高引 火点化に着目することによる，日本の消防法への対応， また高引火点ベースオイルによる環境対応（作業環境性 の改善）の具体例について，次項より紹介したい。

Table 1 潤滑油のベースオイルとその特徵

\begin{tabular}{c|c|c|c}
\hline \multicolumn{2}{|c|}{ 分類 } & 特徵 & 適用潤滑油 (一例) \\
\hline \multirow{2}{*}{ 鉱物油系 } & パラフイン系 & 汎用性が最も高い & エンジンオイル, 汎用工業油 \\
\cline { 2 - 4 } & ナフテン系 & $\begin{array}{c}\text { ワックスを含まない } \\
\text { 溶解性が比較的高い }\end{array}$ & $\begin{array}{c}\text { 絶縁油 } \\
\text { ゴム用プロセスオイル }\end{array}$ \\
\cline { 2 - 5 } & オレフイン系 & $\begin{array}{c}\text { 比較的鉱油に近い } \\
\text { 耐熱性に優れる, 低流動点 }\end{array}$ & 極低·高温用特殊環境潤滑油 \\
\cline { 2 - 5 } & エステル系 & 潤滑性に優れる, 難燃性 & 難燃性作動油 \\
\cline { 2 - 5 } & エーテル系 & 耐熱性, 耐薬品性に優れる & 不燃性作動油, 宇宙機器用潤滑油 \\
\hline & 植物油系 & 生分解性に優れる & 船用エンジン, チェーンソー \\
\hline
\end{tabular}




\section{3 潤滑油の高引火点化}

\section{3・1 日本の消防法と高引火点潤滑油}

潤滑油は石油製品であることからも，半固体状潤滑剂 であるグリースや水を含む水溶性切削油等を除き，その 多くが引火性を有している。労働安全衛生法には,「引 火性の物」と規定した規律分類はあるものの，その分類 は引火点 $65^{\circ} \mathrm{C}$ 未満が対象となっており，多くの潤滑油 が対象外となる。

一方で消防法の区分上では，潤滑油の危険物第四類の 第三および第四石油類，可燃性液体類に分類される ${ }^{9)} 。$ 特に潤滑油を多く使用する工場では，消防法にて規定さ れた取扱数量を遵守する必要があり, その取扱数量は各 危険物分類によって決定される。つまり, 潤滑油の引火 点そのものが取扱数量を決定する大きなファクターとな るため, 潤滑油の引火点というものは生産現場にて使用 する上でも，また管理する上でも非常に重要なパラメー
夕となる。

中でも平成 13 年 7 月の消防法の改正により平成 14 年 6 月から引火点 $250^{\circ} \mathrm{C}$ 以上の潤滑油は危険物から除外さ れ, 可燃性液体類として取扱われるようになった。この 消防法の改正が, 潤滑油メーカー各社での高引火点潤滑 油の開発が大幅に加速する契機となった ${ }^{10,11) 。 ~}$

Table 2 に改正後の第 3 石油類（引火点: $70^{\circ} \mathrm{C}$ 以上 $200^{\circ} \mathrm{C}$ 未満）ならびに第 4 石油類（引火点： $200^{\circ} \mathrm{C}$ 以上 $250^{\circ} \mathrm{C}$ 未満), 可燃性液体類の取扱いの違いを示す。引火 点が $250^{\circ} \mathrm{C}$ 以上の潤滑油は第 4 石油類から外れても可然 性液体類として分類される。可燃性液体類は数量 2 立方 メートル $(2,000 \mathrm{~L})$ 以上で指定可燃物となり市町村条 例の規制を受けるため, 所轄消防署への届出が必須とな るが, 少量危険物（危険物取扱量が指定数量の $1 / 5$ 以上, 指定数量未満の場合）と同等の取扱いが可能となる。特 に，工場内に新しい機械を増設し，少量危険物取扱所か ら一般危険物取扱所になる場合や, 新設工場建設時に最

Table 2 可燃性液体類およびその他危険物分類潤滑油の取扱いについて ${ }^{10)}$

\begin{tabular}{|c|c|c|c|c|}
\hline $\begin{array}{c}\text { 消防法による } \\
\text { 分類 }\end{array}$ & 取扱数量 & 適用 & 届出許可申請 & $\begin{array}{c}\text { 貯蔵·取扱いにおける } \\
\text { 技術上の基準 }\end{array}$ \\
\hline \multirow{2}{*}{ 可燃性液体類 } & 2,000L未満 & 指定可燃物対象外 & - & - \\
\hline & 2,000 L以上 & 指定可燃物 & 指定可燃物貯蔵取扱所 & 市町村条例 \\
\hline \multirow{2}{*}{$\begin{array}{c}\text { 第4類 } \\
\text { 第3石油類 }\end{array}$} & 400L以上 2,000 L未満 & 少量危険物 & 少量危険物貯蔵取扱所 & 市町村条例 \\
\hline & $2,000 \mathrm{~L}$ 以上 & 危険物 & $\begin{array}{c}\text { 危険物の製造所, } \\
\text { 貯蔵所および取扱所 }\end{array}$ & 政令 \\
\hline \multirow{2}{*}{$\begin{array}{c}\text { 第4類 } \\
\text { 第4石油類 }\end{array}$} & 1,200 L以上 6,000 L未満 & 少量危険物 & 少量危険物貯蔵取扱所 & 市町村条例 \\
\hline & 6,000 L以上 & 危険物 & $\begin{array}{c}\text { 危険物の製造所, } \\
\text { 貯蔵所および取扱所 }\end{array}$ & 政令 \\
\hline
\end{tabular}

Table 3 高引火点潤滑油（可燃性液体）の採用によるコスト削減事例

\begin{tabular}{|c|c|c|}
\hline 業種 & コスト削減例 & 削減額, 円 \\
\hline \multirow{3}{*}{$\begin{array}{c}\text { 精密機械 } \\
\text { 製造業 }\end{array}$} & 新設工場の建設 & \multirow{3}{*}{ 約6億 } \\
\hline & 可燃性液体の加工油·設備油を採用 & \\
\hline & 不燃材使用コスト、防爆·消化設備の設置費削減 & \\
\hline \multirow{3}{*}{$\begin{array}{c}\text { 自動車 } \\
\text { 部品製造業 }\end{array}$} & 設備増強による危険物保有量の指定数量オーバー & \multirow{3}{*}{ 約1億5千万 } \\
\hline & 油圧作動油を可燃性液体へ切替え & \\
\hline & 防火壁·天井への改造費、消化設備の増設費削減 & \\
\hline \multirow{3}{*}{$\begin{array}{l}\text { プ ラスチック } \\
\text { 加工業 }\end{array}$} & 新設工場 (成形機:30台)建設 & \multirow{3}{*}{ 約1億3千万 } \\
\hline & 可燃性液体の作動油を採用 & \\
\hline & 耐火構造·排煙設備·消化設備費の削減 & \\
\hline
\end{tabular}




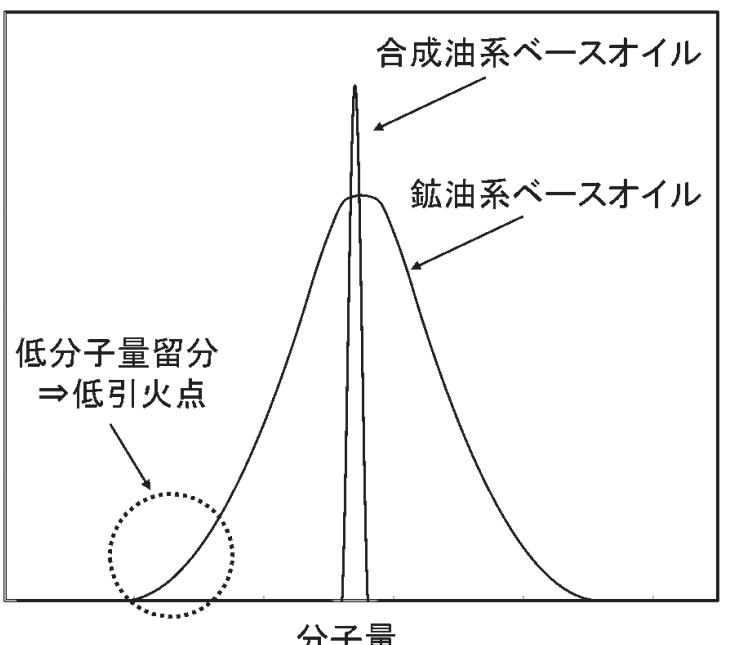

分子量

Fig. 1 ベースオイルの分子量分布イメージ

初から可燃性液体類である高引火点潤滑油の全面採用を 前提に建屋を建設するのでは, Table 3 の例に示すよう に各種設備にかかるコストに大きな差（～数億円）が発 生する。このように消防法対応に伴う高引火点潤滑油の 適用は，安全性の観点のみならずコストメリットに大き く寄与することからも, 潤滑油の高引火点化は非常に重 要な課題であることがわかる。ただし，ギヤー油および シリンダー油のみ品目指定で第四石油類に指定されてい るため，引火点が $250^{\circ} \mathrm{C}$ を超えた場合に打いても可燃性 液体類とならないことに注意が必要である。

\section{$3 \cdot 2$ 潤滑油の高引火点化}

前述にもあるように, 潤滑油の 8 割 $~ 9$ 割はべースオ イルによって構成されているため, 潤滑油の引火点にお ける支配因子は凡そベースオイルに依存する。特に大半 の潤滑油は原油を精製した鉱物油系ベースオイルが使用 されているが，鉱物油は水や合成油と異なり，単一物質 ではなく混合物である。より分かりやすく説明するため, 鉱物油系ベースオイルと合成油系ベースオイルの分子量 分布のイメージ図を Fig. 1 に示す。Fig. 1 に示すように, 通常の鉱物油は分子量の異なる各種炭化水素が混合され て一つの粘度グレードとなっている。特にこの低分子量 側の留分が引火点を下げてしまうことから，潤滑油自体 の引火点を向上させるためには，分子量分布が狭い鉱物 油系ベースオイル（ナローカットと呼ばれる）を採用す るか，合成油系を採用する必要が生じる。

鉱物油系ベースオイルと合成油系ベースオイルにおけ る $40^{\circ} \mathrm{C}$ 動粘度と引火点の関係性を Fig. 2 に示す ${ }^{12)}$ 。Fig. 2 からも明らかなように, 同等の動粘度で比較した場合, 合成油系ベースオイルの方が鉱物油系ベースオイルと比 較して高い引火点を示していることが見て取れる。これ はFig. 1 でも示したように, 鉱物油は低分子量側の留分

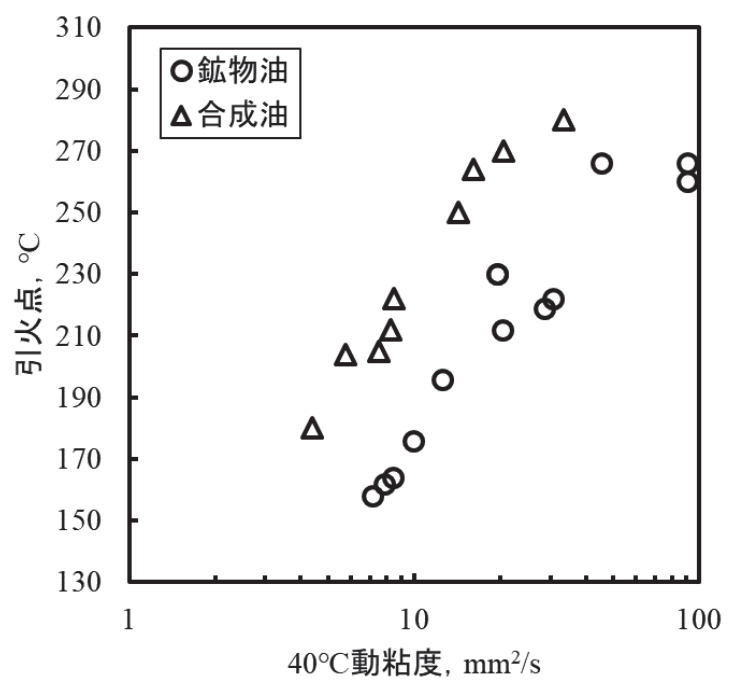

Fig. 2 各種ベースオイルの粘度と引火点の関係 ${ }^{12)}$

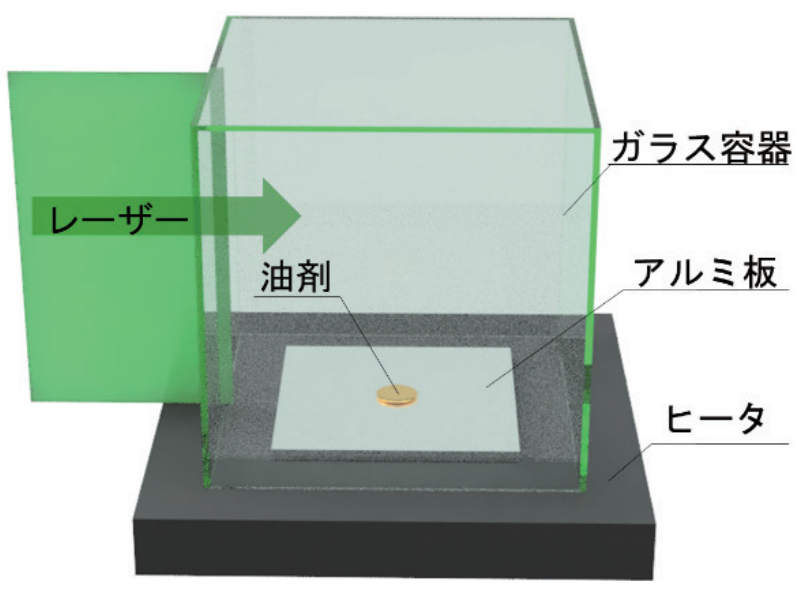

Fig. 3 ヒューム発生試験の概要

が大きく影響を及ぼしているためである。また鉱物系， 合成系のどちらに打いても，高粘度であるほど高引火点 を示すことがわかる。これは高分子量留分が多いことに 加え, 高粘度であるほど分子間の相互作用が強く, 気化 しにくくなるため引火点が高くなることに由来してい る。

以上からも, 潤滑油の高引火点化には最適なベースオ イルの選択が非常に重要となる。また潤滑油の適用先に よっては添加剤を多く配合しなければいけない油種もあ るため, 添加剤の種類によっては引火点の低下を引き起 こす可能性があることから, 潤滑油開発の際には添加剂 の選定にも留意しなければいけない点もある。

\section{$3 \cdot 3$ 高引火点油剤による作業環境の改善}

近年の生産現場では消防法をはじめとした法規制に対 応したニーズの他に, 製造のコスト競争力強化のために 生産の高効率化や環境意識の高まり，また人体への負荷 低減といった付加価值が新たに求められる傾向にある。

例えば金属加工の一種である切削に使用される潤滑油 
（不水溶性切削油）を例に挙げると，近年の高効率化に 伴い加工負荷が高くなる傾向にある。つまり，切削油が 従来よりも過酷な条件で使用される傾向にあり, 加工の 高速・高送り化や難削材 (チタン合金, ニッケル合金等) の増加が従来の加工に比べて切削温度を上昇させ, ベー スオイル起因のヒューム (油煙) の発生を引き起こして いる。このヒュームは生産現場の視認性の低下のみなら ず，吸入による人体への健康被害を引き起こす可能性が あることから，近年問題視されている。本項では，これ ら作業環境性の改善に不水溶性切削油の高引火点化が寄 与した事例について紹介する ${ }^{13)}$

ヒュームの発生要因は引火点と大きく関係している。 引火点とは, 物質の可燃性蒸気と空気の混合気が点火源 により引火する温度であり, 引火点が低いということは
可然性蒸気が発生し易いということを意味する。つまり ベースオイルに含まれる低分子量側の留分が多ければ多 いほど，切削加工における加工熱により気化し易く， ヒュームが多く発生することになる。加えて, 不水溶性 切削油は 5 $32 \mathrm{~mm}^{2} / \mathrm{s}$ の低粘度油が一般的に使用され ており，ヒュームによる影響が顕著に現れやすい油剤で ある。

ここでヒュームの発生量を比較すべく，40ㄷ 動粘度が 約 $8 \mathrm{~mm}^{2} / \mathrm{s}$, 約 $20 \mathrm{~mm}^{2} / \mathrm{s}$ の鉱物油系ベースオイルと合 成油系ベースオイルを供試油として, 弊社にて可視化試 験を実施した結果を紹介する。Fig. 3 に示すとおり， $170^{\circ} \mathrm{C}$ に熱したアルミ板にスポイトで供試油を滴下し, ガラス容器を被せて観察を実施した。尚, 観察時にヒュー ムの発生をより可視化すべく, シート状のレーザーを当

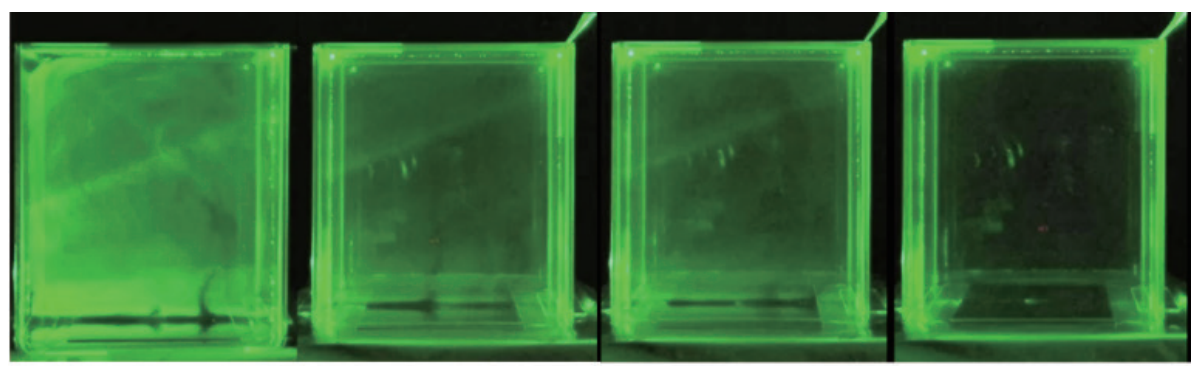

鉱物系 $/ 8 \mathrm{~mm}^{2} / \mathrm{s}$ 合成系 $/ 8 \mathrm{~mm}^{2} / \mathrm{s}$ 鉱物系 $/ 20 \mathrm{~mm}^{2} / \mathrm{s}$ 合成系 $/ 20 \mathrm{~mm}^{2} / \mathrm{s}$

Fig. 4 各種ベースオイル滴下後 30 秒後のヒューム発生状況

Table 4 切削加工条件

\begin{tabular}{|c|c|}
\hline 被削材 & SCM435(クロムモリブデン鋼) \\
\hline インサート & VP15TF CNMG120404-MS（三菱マテリアル） \\
\hline 切削速度 & $300 \mathrm{~m} / \mathrm{min}$ \\
\hline 送り & $0.1 \mathrm{~mm} / \mathrm{rev}$ \\
\hline 切り込み & $1.0 \mathrm{~mm}$ \\
\hline
\end{tabular}

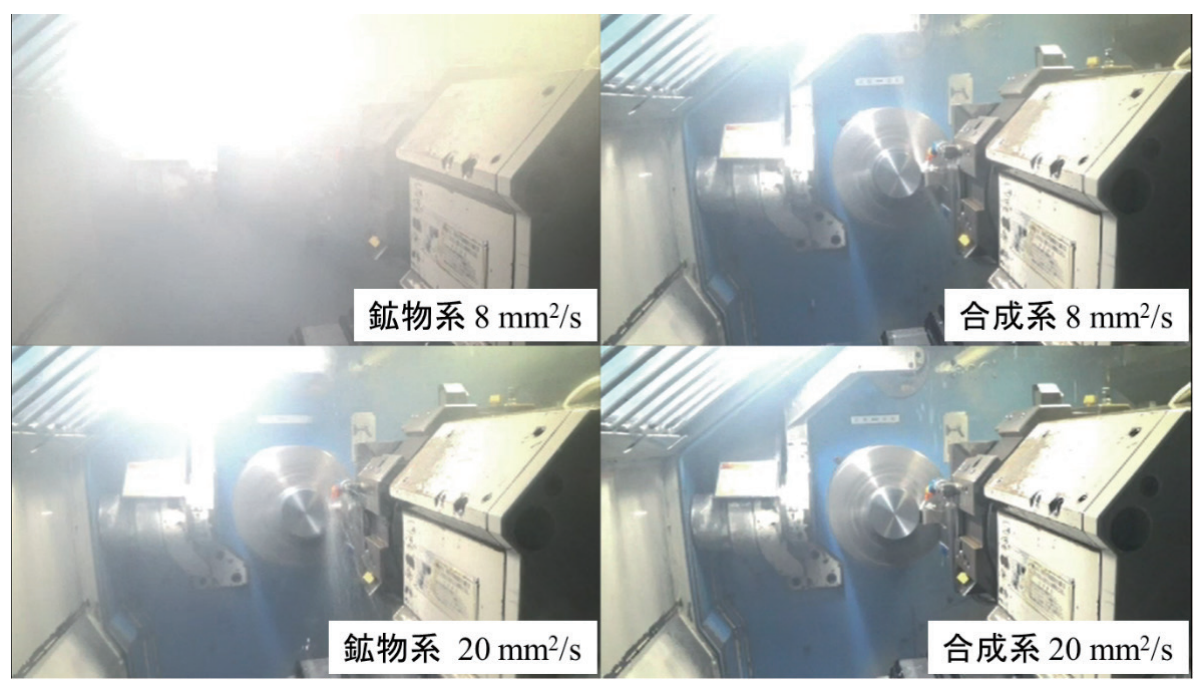

Fig. 5 旋削加工時における工作機械内のヒューム発生状況 ${ }^{13)}$ 
てた。供試油を滴下して約 30 秒後の外観を Fig. 4 に示す。

Fig. 4 からも明らかなように, 高粘度のベースオイル の方が低粘度のベースオイルと比較してヒュームの発生 量が少なく, 合成油系ベースオイルの方が鉱物油系ベー スオイルと比較してヒュームの発生量が少ないことがわ かる。本傾向は引火点と同様の傾向であることからも, 引火点がヒューム発生量に大きな影響を及ぼしているこ とがわかる。

続いて，実際に切削加工が行われている生産現場を模 擬すべく，同じ供試油を用いて合金鋼（SCM435）の旋 削加工を実施し，工作機械（NC 旋盤）内のヒューム発 生の様子を観察した。加工試験における切削条件を Table 4 に，NC 旋盤内にカメラを設置して加工時の様 子を撮影した結果を Fig. 5 にそれぞれ示す。

Fig. 5 からも明らかなように, 実際の切削加工時にお いてもヒューム発生試験と同様に, 低粘度のベースオイ ルと比較して高粘度のベースオイルの方が, また鉱物油 系ベースオイルよりも合成油系ベースオイルの方が ヒューム発生量が少なくなり，工作機械内での視認性は 大きく改善されることがわかる。本試験に加えて, ピエ ゾバランス式の粉塵計（日本カノマックス社製, Model 352）を用いて，旋削加工中に NC 旋盤の屝のすき間か ら漏孔出る飛散成分発生量の定量化を試みた。尚, ここ で言う飛散成分とは, 旋削加工時の切削熱で発生する ヒュームに加え, ポンプでの給油に伴う切削油のミスト 化も発生するため, ここでは飛散成分量として定義して いる。加工試験における切削条件は Table 4 と同条件で 実施し，測定した結果を Fig. 6 に示す。

本結果より，いずれの動粘度においても合成油系べー スオイルは鉱物油系ベースオイルと比較して約 $60 \%$ も 飛散成分が削減され，たとえ鉱物油系ベースオイルで あっても高粘度のベースオイルの方が約 $65 \%$ も飛散成 分が少なくなることがわかる。

以上より，生産現場での作業環境性向上のためには潤 滑油の高引火点化が非常に有効であり, 中でもヒューム 低減に伴う生産現場の視認性向上, 健康被害リスクの低 減といった効果が期待できる。そのため, 高引火点潤滑 油の開発の際には高粘度化に加え, 合成油系ベースオイ ルの選定がキーポイントとなる。ただし，金属加工にお いては加工形態や加工条件に応じて最適な粘度を有する 潤滑油を選択する必要があるため, 高粘度ベースオイル を使用することは必ずしも望ましくなく, 適切な合成油 を選択することが求められる。

\section{4 おわりに}

本項では潤滑油におけるベースオイルの種類およびそ

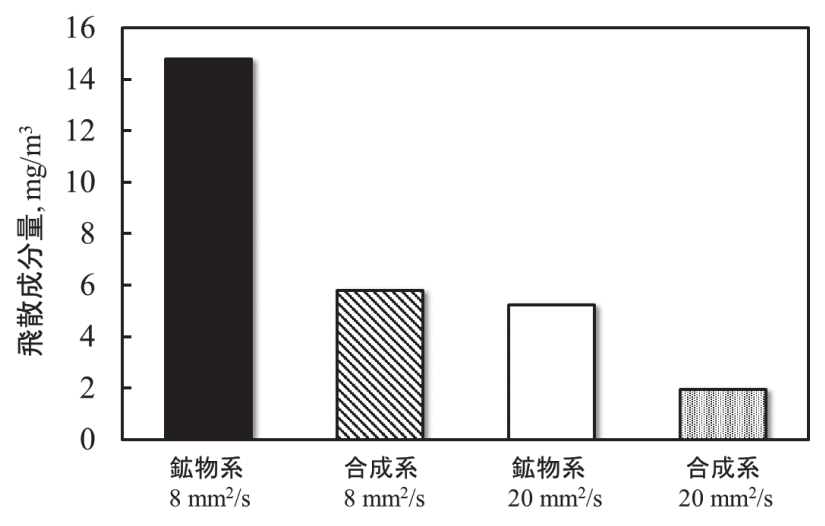

Fig. 6 ピエゾバランス式粉塵計にて測定した工作機械内の 飛散成分量

の役割について説明するとともに, 潤滑油の高引火点化 を例にとった消防法への対応, 生産現場の作業環境性改 善効果について概説した。しかし自動車・機械技術をは じめとした産業の進展はめざましく, 筆者が本稿を執筆 している間にも新しい産業技術は生まれており, その技 術に付随して新たな潤滑油が開発されている。潤滑油は 目立たない存在であるが, 産業を支える必須の製品であ ることは間違いない。

また昨今の安全感度・環境意識の高まりから, 潤滑油 に求められる性能も年々増えており, 本稿では紹介する ことができなかったが，これまでもべースオイル技術を 中心とした潤滑油技術の進展により課題解決を実現して きた。身近なものを例に挙げると, 冷蔵庫やエアコンに 使用されている冷凍機油は, 1987 年のモントリオール 議定書をはじめとする冷媒の規制・変化に合わせながら， ポリアルキレングリコールやポリビニルエーテルをはじ めとする合成基油が新たに開発され，今日の冷凍機油と して主に使用されている ${ }^{14)}$ 。また油圧機器に主に利用 される油圧作動油では, 1998 年に改正された「省エネ法」 をきっかけとして, 潤滑油による省電力・高効率化の検 討が進められ, 低粘度基油および最適な摩擦調整鼡の適 用により，消費電力を 2〜 5\%低減する省エネ化を実現 してきた ${ }^{15)}$ 。

近年では, 2015 年に採択された「持続可能な開発目 標 (SDGs)」が話題であり, 環境意識はこれまで以上に 高まっていることからも, 今まで以上に潤滑油に求めら れる性能目標は高くなることが予想される。このような 時流・環境を敢えてチャンスとして捉え，今まで以上に 潤滑油開発が活発化し, 技術レベルが向上することを期 待したい。

文 献

1）山本雄二, 兼田槇宏, トライボロジー, 理工学社 (1998). 
(Yamamoto, Y. et al. Tribology, Rikogakusha Publishing Co.,Ltd. (1998).)

2）浜口仁，世界の潤滑油／潤滑油添加剂技術と市場 - 規 格動向, S\&T 出版, 4 (2014).

(Hamaguchi, H. World Market of Lubricants, S\&T Publishing Inc. (2014).)

3）浜口仁, トライボロジスト, 61, 665 (2016).

(Hamaguchi, H. Journal of Japanese Society of Tribologists 61, 665 (2016).)

4）渡辺治道, トライボロジスト，50，277（2005）.

(Watanabe, H. Journal of Japanese Society of Tribologists 50, 277 (2005).)

5）渡嘉敷通秀, 有機合成化学, 43, 704 (1985).

(Tokashiki, M. Journal of Synthetic Organic Chemistry, Japan 43, 704 (1985). )

6）足立之彦, トライボロジスト， 64, 135 (2019).

(Adachi, Y. Journal of Japanese Society of Tribologists 64, 135 (2019).)

7）高柳正明, オレオサイエンス， 5，455 (2005).

(Takayanagi, M. Oleoscience 5, 455 (2005).)

8）ジョン・イーストウッド, トライボロジスト, 64, 144 (2019)

(Eastwood, J. Journal of Japanese Society of Tribolo- gists 64, 144 (2019). )

9）出光興産：潤滑油と法規制, https://www.idss.co.jp/ business/lube/about/understand/law01/

(Idemitsu Kosan Co., Ltd. https://www.idss.co.jp/business/lube/about/understand/law01/)

10）松山雄一, 出光トライボレビュー, 25, 1547 (2002).

(Matsuyama, Y. Idemitsu Tribo Review 25, 1547 (2002). )

11）白神善隆, 出光トライボレビュー, 29, 1808 (2006). (Shirakami, Y. Idemitsu Tribo Review 29, 1808 (2006). )

12）浅田佳史, 月刊トライボロジー, 379, 16 (2019). (Asada, Y. The Tribology 379, 16 (2019).)

13）服部秀章, 近藤隆史, 出光卜ライボレビュー, 41, 2558 (2018)

(Hattori, H. et al. Idemitsu Tribo Review 41, 2558 (2018).)

14）東條健司，トライボロジスト，59，426（2014）.

(Tojo, K. Journal of Japanese Society of Tribologists 59, 426 (2014). )

15）置塩直史, トライボロジスト，59，400（2014）.

(Oshio, T. Journal of Japanese Society of Tribologists 59, 400 (2014). ) 